\title{
What Should a Sustainable Economy Sustain? The case for a just economy
}

\section{Citation}

Marglin, Stephen, and Tariq Banuri. 2013. "What Should a Sustainable Economy Sustain? The Case for a Just Economy." Development 56 (1) (March): 79-85. doi:10.1057/dev.2013.14. http:// dx.doi.org/10.1057/dev.2013.14.

\section{Published Version}

doi:10.1057/dev.2013.14

\section{Permanent link}

http://nrs.harvard.edu/urn-3:HUL.InstRepos:25658991

\section{Terms of Use}

This article was downloaded from Harvard University's DASH repository, and is made available under the terms and conditions applicable to Open Access Policy Articles, as set forth at http:// nrs.harvard.edu/urn-3:HUL.InstRepos:dash.current.terms-of-use\#OAP

\section{Share Your Story}

The Harvard community has made this article openly available.

Please share how this access benefits you. Submit a story.

\section{Accessibility}




\title{
What ShOULD a Sustainable Economy Sustain?
}

\author{
The Case For a Just Economy
}

\author{
Stephen Marglin and Tariq Banuri
}

Keywords: Climate change, climate justice, discount rate, ecological economics, equity, sustainability, sustainable development, technological optimism

This essay raises a simple question: Do the ecological issues the world faces-the filling of sinks and the emptying of sources-require far-reaching changes in values, knowledge systems, or political structures? Or can these issues be addressed by marginal changes in policies and to formal governmental institutions?

These are old questions, about which activists and intellectuals have long disagreed. ${ }^{1}$ The disagreement extends to the economics profession, and is central to the contentions over the meaning and aims of the green economy. One group-let us call them "ecological economists" even though ecologists hardly speak with one voice-are pessimistic about the possibility of technological solutions alone; they call for a reduction in material consumption in the rich North while arguing with equal conviction for growth in the poor South. ${ }^{2}$ A second group, "mainstream economists"who are only marginally more homogeneous than ecologists-argue that technology will, reliably, come to the rescue-driven by the market's invisible hand acting alone, or aided by the visible hand of enlightened government policies. They see no need for drastic action to reduce consumption; only some tinkering at the margins to facilitate technological fixes. ${ }^{3}$

We argue that this disagreement cannot be resolved within the discipline, namely by assessing the relative merits of the technical arguments or the validity of the empirical evidence offered by these two groups. Instead, an external framework-the framework of environmental justice-can help in the comparison by bringing out the underlying assumptions and social and political implications of the two contrasting views.

This is not an idle debate over broad philosophical constructs. Rather, without such a strategic conception, it is impossible to reach social consensus-or even engage in a meaningful political debate-over the practical steps or tactics for addressing the finiteness of sinks and sourcesincluding, for example, the concrete policies or actions under the rubric of the rhetorical agreement over the green economy. For example, there is currently a great deal of interest in a carbon tax as a means of addressing global warming. Carbon tax is one thing if we are talking about taxes that would bring the price of gasoline in the US say to $\$ 10$ per gallon (it is below $\$ 4.00$ as we write this), quite another if we are talking about taxes that would bring the price to $\$ 50$ or $\$ 100$ or even $\$ 1,000$ per gallon.

\footnotetext{
1 The classic example of this debate is the wager between the biologist Paul Ehrlich and the cornucopian economist Julian Simon over the price of five key commodities between 1980 and 1980 . Ehrlich believed that emerging resource constraints would lead to a price increase while Simon held that markets and technology would come to the rescue. In the event, the prices failed to rise and Ehrlich lost the bet, but as several ecologists have argued, this was because both had an imperfect understanding of the behavior of prices. See, e.g., Philip Lawn, "On the Ehrlich-Simon bet: Both were unskilled and Simon was lucky", Ecological Economics 69 (2010): 2045-46.

${ }^{2}$ See, e.g., Andrew Simms, Victoria Johnson, and Peter Chowla, Growth Isn't Possible, New Economics Foundation, 25 Jan 2010, http://www.neweconomics.org/publications/entry/growth-isnt-possible.

${ }^{3}$ See, e.g., Bjorn Lomborg, Cool It: The Skeptical Economist's Guide to Global Warming. Knopf, 2007. While Lomborg is at the extreme end of the spectrum, his optimism regarding the potential role of the market is widely shared in the economics profession.
}

This is a post-peer-review, pre-copyedit version of an article published in Development 56(1):79-85, 2013. The definitive publisherauthenticated version is available online at: http://www.palgrave-journals.com/development/journal/v56/n1/full/dev201314a.html. 


\section{The Economic View of Climate Chaos}

In some respects sinks and sources pose similar problems, but the differences are crucial. For several reasons technological fixes have been invoked far more often in relation to sinks than to sources. Think about catalytic converters to eliminate lead from petrol, scrubbers to capture sulfur emissions, exhaust controls for cement plants, the list is endless. Innovative sink technologies are already available in many contexts and many others are on the drawing boards. Brave new solutions are proposed even where there are doubts about their efficacy or safety-such as nuclear waste disposal or carbon capture and storage.

To recall our two protagonists, the ecological and mainstream economists, the latter are optimistic not only about the ability of a free market system to find technological solutions-whether the problem is the ozone layer, global warming, or oil depletion-but also about its ability to adjust consumption to the dictates of resource limits. They point to a history of human ingenuity that has averted crisis. For instance, limits on the availability of wood and coal for heat and transport, or whale oil for light, were recognized in the nineteenth century, and it was hardly unreasonable to worry about a future without adequate forests, coal reserves, and whales. The discovery of petroleum removed these concerns. So will it be in the future: technology will provide another source of energy when we have depleted existing sources of petroleum.

Ecologists, on the other hand, see the future as a game of Russian roulette-just because the bullet doesn't end up in front of the firing pin the first few times you spin the barrel of your revolver, you have no guarantee that it won't be there the next time. And if you keep playing long enough, you can be confident that sooner or later you'll run out of luck. They argue that the world has neither the requisite technological fixes to address the main sink, the atmospheric absorption of $\mathrm{CO}_{2}$, nor sufficient time to do so through a reduction in the material standard of living in the North. Such an adjustment is the work of generations, not decades, but by most accounts we have decades, and not very many of them, to address the problem of global warming.

\section{The Ecological Economics Critique}

Two economists, Herman Daly and the late Kenneth Boulding, pioneered the argument that mainstream economics fails to take adequate account of the ecological constraints under which the economy operates. Boulding made a distinction between open system "cowboy" economics and closed system "spaceman" economics. Cowboy economics assumed virtually unlimited sources of resources accompanied by equally unlimited sinks in which to throw the garbage. "Spaceman" economics offers no outside sources or sinks-just a closed system consuming energy solely from the sun and recycling its own waste. ${ }^{4}$ Daly similarly distinguishes between an economics that has to deal with localized externalities from an economics that must address pervasive externalities. ${ }^{5}$ In short, the message of Daly and Boulding is that mainstream economics is all well and good when the impact of the economy on the environment and the resource base is small, but that this same economics becomes irrelevant when we are up against ecological constraints.

Note that the central issue highlighted by this critique is that of economic growth. In principle, as is recognized in mainstream economics, neither the problem of externalities nor the problem of resource depletion is predicated on economic growth; a stationary, non-growing economy also pollutes and draws on fixed resources. The key point of the critique is that economic growth transforms the economy to the point that mainstream economics may no longer be adequate to diagnose problems or prescribe solutions. With growth, externalities that might be marginal annoyances can become threats to survival. My neighbor's chimney pollutes, but if I have only one

4 Boulding, Kenneth. 1966. "The Economics of the Coming Spaceship Earth." In H. Jarrett, ed., Environmental Quality in a Growing Economy. Baltimore: Johns Hopkins Press, pp. 3-14.

${ }^{5}$ Daly, Herman, and John Cobb Jr. 1989. For the Common Good: Redirecting the Economy toward Community, the Environment, and a Sustainable Future. Boston: Beacon Press. 
neighbor in a quarter-mile radius, I can probably live with the externality of the smoke from his hearth fire. Not so if I live cheek to jowl with many neighbors. Similarly with a natural resource like oil: with or without growth, the oil we use today is not available tomorrow or the day after, but the problem becomes more severe for the day after tomorrow if tomorrow's oil consumption is double today's.

Moreover, exponential growth can burst on our consciousness with explosive force. The problem is captured in a parable critics tell about an area's pond lilies that double in area every day. If the pond is going to be full of lilies on the thirtieth day, on which day will the pond be half full? The answer, counter-intuitive for some, is the twenty-ninth day.

However, while Boulding and Daly illuminated how best to comply with resource and environmental constraints, both beg the question of when the environment and the resource base will become binding constraints. If the day when the lily pond becomes full is December 31, 2049, or even December 31, 2099, most of us would agree that responsible people cannot escape the need to do something now. But if the day of reckoning is December 31, 2999, most of us might agree with Bjorn Lomborg that we needn't be in too much of a hurry. If the day of reckoning is far enough in the future, ecological problems may be manageable; if it is close at hand, we may need to go beyond the market, and well beyond economics, in searching for ways to reduce the quantity of resources we use and the volume of garbage we spew out.

So which is it: one hundred or one thousand years? With respect to some issues-global warming for example-there is a broad scientific consensus that the day of reckoning is close at hand. For other issues-like a global collapse of fisheries - the crystal ball is murkier. More to the point, we have only a poor idea of the cost of mitigating global warming or the cost of substitutes for fossil fuels. In any case, whether we make much or little of ecological constraints depends more on psychology than on science, the optimism of the cornucopian economists pitted against the pessimism of ecologists.

In any event, the idea that the world does not have time to address global warming through a reduction of the material standard of living in the North seems to strike mainstream economists as odd. Since 2006, much of the economic debate over climate change has been structured around the framework provided by the Stern Review $(2006)^{6}$, which characterizes the problem as one of trading off consumption in this century against a permanent increase in consumption in the following centuries. Stern suggests that through timely commitment of 1 percent of global GDP to address the causes of global warming, the world can avoid a permanent loss of 5 percent (or more) of global GDP. The message is simple: the economics of climate change favor action over inaction; an investment of one dollar today will save five dollars tomorrow.

\section{The Side Debate Over the Discount Rate}

Interestingly, however, the heated debate within the economics profession has not been about whether this can be done, but whether it is desirable in the first place-in other words, whether the explanation for inaction is simply that action is not needed. To wit, the mainstream of the economics profession has taken issue with Stern's conclusion because of a perceived flaw in the metric he uses to compare future benefits with present costs. ${ }^{7}$ The argument hinges on the discount rate, the rate by which future benefits (and costs) are reduced ("discounted") to reflect two standard economic assumptions about the future, first, that the world might end before the benefits can be enjoyed or the costs incurred, and, second, that as a result of economic growth, wants and needs will be less pressing in the future than in the present, with the result that a given quantum of benefits and costs amount to less of a gain or sacrifice than the same quantum today.

${ }^{6}$ See Nicholas Stern, The Economics of Climate Change: The Stern Review. Cambridge University Press, 2007

${ }^{7}$ For a critique, see, e.g., William Nordhaus, The Stern Review on the Economics of Climate Change, 3 May 2007, Yale University. For a more balanced view, see Martin L. Weitzman, A Review of the Stern Review on the Economics of Climate Change, Journal of Economic Literature, 2007, 45(3): 703-24. 
Most economists' criticism is directed against the Stern Review's alleged failure to take proper account of the so-called "opportunity cost" of capital in its choice of a relatively low discount rate. A higher, opportunity-cost based, discount rate would have downgraded the future costs of climate change (and therefore the future benefits of addressing global warming) in this century, to the point that some critics claimed the game of climate stabilization is not worth the candle, at least not now.

This is not a dispute that we need enter because it is a classic case of searching for the car keys under the lamppost. ${ }^{8}$ There is a long-standing debate among economists about the appropriate rate of discount from a societal point of view. Suffice it to say that economists are very comfortable in arguing various positions in this debate, which like many in economics is never settled, only sidelined, sometimes for decades at a time.

However the implication of this esoteric debate is worth noting-namely that the estimated costs of even the worst-case scenarios of climate change do not justify more than the minimal action that is already in place. As we know, the worst-case scenarios are horrific, and even the "acceptable" scenarios are beyond grim. Stern describes a world with the stock of greenhouse gases stabilized at $550 \mathrm{ppm} \mathrm{CO}_{2} \mathrm{e}$ "a very dangerous place", and one potentially resulting in "the deaths of hundreds of millions of people (due to food and water shortages and extreme weather events)." (Stern Review, Part 3, ch 13, pp 292-293) ${ }^{9}$ The figure for deaths is not a typo, that's hundreds of millions. Nevertheless $550 \mathrm{ppm} \mathrm{CO}_{2} \mathrm{e}$ is the target that the Stern Review takes as the best that can be done and good enough. It is largely because the Stern Review is willing to countenance the world as a very dangerous place that the problem of global warming can be addressed at a cost equal to an annual equivalent of 1 percent of global GDP. Yet, a strict adherence to economic purity would place even this relatively less grim scenario beyond reach because it would mean sacrificing as much as 1 per cent of the global income of the current generation in order to save the lives of hundreds of millions in future generations.

\section{The Real Trade-off}

In fact, there is a better way of examining this debate. Global warming's real trade-off does not occur between a representative economic agent of this century and the representative agent of subsequent centuries. It is, instead, among familiar parties: The citizens of the North and South, to whom we impute averages of gains and losses, costs and benefits. On the one hand is the well-being of the North, who have historically benefited in material terms from filling up the atmospheric sink with greenhouse gases, are relatively insulated from the impacts of global warming, and in any case will have the resources to address all but the worst case scenarios of global warming should they materialize. On the other hand, the citizens of the South, who are most exposed to these worst-case scenarios lack the resources to deal with them.

If the trade-off between the relatively immune North to the threatened South is the one on which we should focus, the moral alternative to a technological fix is not inaction based on a calculus of future benefits and present costs, but a transfer of income and wealth. Transfers are second best, an alternative only if the technological fix falls short, for two reasons. Transfers are neither morally sufficient-how do you compensate people for the loss of their way of life, as distinct from their way of making a living? - nor politically likely—think Darfur and other humanitarian interventions which

\footnotetext{
${ }^{8}$ A passerby comes upon an economist searching for his lost keys under a lamppost. The economist complains that he has been searching for half an hour without success. "Well, where did you last have your keys?" asks the passerby. The economist replies, "Oh, somewhere down the road," to which the passerby quite sensibly asks, "Then why are you looking here?" "Because the light is much better here..."

9 It has to be stressed here that the Stern Review is concerned with dangers that cannot be meaningfully quantified in terms of probabilities, either because the science is opaque or because the scientific processes are inherently unpredictable. We are squarely in the realm of radical uncertainty, as distinct from the probabilistic calculus with which economists are comfortable.
} 
have not taken place. Besides the technological fix, there is a case to be made for substantial transfers of income from North to South should the technological solution prove inadequate.

Global warming is, so to speak, the tip of an iceberg. One can argue that a sacrifice of 1 percent of GDP, the order of magnitude on which the Stern Review settles as the cost of combating global warming, is no sacrifice at all. At least if it is spread equally among the world's population: even for the poor, a 1 percent reduction in consumption is arguably below any perceivable threshold, so provided that mechanisms are in place to share the burden equally-obviously no easy matter-then we can regard the costs of combating global warming as trivial. (Even if these costs were entirely absorbed by the North, the material standard of living would be so little changed that the transition to a stabilized climate regime can be said to be costless.)

\section{An Alternative Approach}

Who is right? We may be able to answer by looking outside the debate between congenitally optimistic mainstream economists and congenitally pessimistic ecological critics. Consider the problem in terms of game theory, as one of choosing whether to act on the assumption that the pessimists are right, and opt for downsizing the Northern economy, or to act on the assumption that the optimists are right, and opt for continued growth. At first glance, this is not terribly helpful because there is no compelling way of choosing whose evidence or analysis to believe, no "dominant strategy." We will be better off believing the pessimists if they turn out to have the better crystal ball, and believing the optimists if their guess is correct.

However, there is another way of looking at the issue. It leads to the same conclusion as the one the pessimists reach, but a very different basis than minimizing the possibility of unpleasant surprises. As has been documented extensively, beyond a certain threshold (roughly $\$ 10,000$ per capita), increases in income do not contribute to increases in human welfare or happiness. ${ }^{10}$ This suggests that most, or at least a good deal, of our consumption is devoted to fulfilling relative wants, wants that come out of our desire for respectability, or status, wants whose fulfillment allows us to "keep up with the Joneses". As such, my consumption creates externalities for you: the more I consume, the worse off you are. And vice versa. In this world, we would all benefit from limits on consumptionindependently of the ecological benefits of these limits. In this world, there may indeed be a dominant strategy: we all may be better off if we assume the pessimists are right and act accordingly, even if in the end it turns out that the optimists were right all along. The reason is that we all would benefit from stepping back from the rat race of work and spend even if the ecological argument for simple living were to turn out to be wrong. The case for limiting consumption is strengthened if we take account of the destruction to human relationships, to community, inherent in the continual search for more, more, and still more, at least in the North, where GDP has long since reached a point that can provide the basis of a decent, dignified life for all.11

In this depiction, we would still describe the payoffs in a matrix with four entries, depending both on the developmental strategy we follow, which is to say whether we heed the pessimists or the optimists, and on who turns out to be right. Even without going through the numbers, it is easy to see that this is a different game from the last one: if we believe the optimists and indulge our tastes for consumption goods, we reduce our satisfactions all around, compared with what is attainable with modest living, because of the negative externality that your consumption has on my well-being (and mine on yours). We do better if the optimists are right than if they are wrong, but not as well as we would have done if we had listened to the pessimists and limited our consumption. Conversely, if we follow the lead of the optimists but the pessimists turn out to be right, we get a double whammy of negative consumption externalities and the ecological damage of high living in a fragile ecology. In

10 See, e.g., Bruno S. Frey and Alois Stutzer, Happiness and Economics, Princeton University Press, 2002, p.75.

11 Stephen Marglin, The Dismal Science: How Thinking Like an Economist Undermines Community. Cambridge, Mass.: Harvard University Press, 2008. 
both cases, we would do better by living modestly in accordance with the pessimistic counsel. Conclusion: whoever is right, we increase our well-being by living modestly. We might be doing the right thing for the wrong reason, but we would at least be doing the right thing.

\section{What is Sustainability?}

What does this argument imply for the future, for what needs to be done, and in particular for the agenda and strategy of the champions of sustainability? First of all, if a correct diagnosis of the ecological crisis suggests that this crisis marks the end of the era of unlimited growth, it will have political implications. In the recent past, the painfully slow progress on poverty eradication and human development was only made possible because it did not detract from the well being of the rich and powerful. If limits to growth begin to assert themselves, there may well be a rearguard action by rich countries and powerful groups to protect their interests through draconian policies and actions. This is one reason why the talk of limits to growth is anathema to poor countries and weak groups - they are justified in fearing that this may herald the advent of an era of oppression and naked coercion.

Second, the temptation to view the ecological crisis as a trade off between the current generation and future generations obscures the other real conflict-that between the powerful and the weak in today's world. The problems confronting the future generation are not restricted to what the present generation will not leave them (namely a rich and vibrant natural world) but also what it will leave them, namely an inequitable and morally unjust world. Herman Daly once described the ethics of the steady-state economy as the ethics of the Sermon on the Mount, "Be not anxious about tomorrow, for tomorrow will be anxious for itself. Sufficient unto the day is the evil thereof."

Third, sustainability means more than ecological sustainability. Apart from its ecological consequences, the singular obsession with growth is problematic because of the toll it takes on human relationships. Sustainability ought to be expanded to include the idea of an economy that sustains these human relationships. This will mean that goods, including the method of delivering the goods (literally), should be scrutinized for their effects on communities, on networks of human relationships, as well as their effects on individual well-being. An economy focused on the individual need not take account of the corrosive effects of markets on community. An economy that takes community into consideration cannot avoid such an examination.

Fourth, in the particular case of climate chaos, there is a temptation to think that the technological fix of renewable energy is just that: a technological fix, and that it need not involve an investigation of the politics of technology. In fact, the situation is far more complex. The multi-billion dollar investment in climate research has raised a number of issues requiring urgent action, but there is minimal prescribed action that may help us address one of the roots of the problem, namely our almost total reliance on fossil fuels. No mainstream political party has called for a moratorium on the exploration of-let alone the extraction of-fossil fuels. Currently, we spend over $\$ 200$ billion per year on exploring for new oil resources and bringing them to the market. Most of the estimates of annual new investments in alternative energy systems are far lower than this figure. Yet, there is no serious proposal to channel the financial resources from such a dead-end and deadly occupation to one that could be the basis of sustaining life on earth.

What this means for a concerted group of activist intellectuals is to help prepare society for change, by systematically and repeatedly articulating a vision based on justice and sustainability, in the broadest sense of those terms. This means, first of all, a clear statement on the dimensions of the problem, a statement that includes an assessment of the limits to growth, and its implications for the society, the polity, and the economy. It means, second, a plan of action and strategy that derives directly from and aims to respond to the entry points in the vision statement. These may include a call for an ethical world as a means of addressing climate change. It may call for a complete and immediate moratorium on the exploration for fossil fuels, and a deadline for a near-total moratorium on their extraction. It may call for a global agreement on consumption in order to ensure both a commitment to sustainability and to ethics. After all this, it may call, finally, for policy choices that can prepare the ground for the more difficult actions that will require longer germination time. 
Since a principal obstacle to such an agenda is the discipline of economics itself, it may also require a sustained investment in the pedagogy of a socially just approach to the study of economics. To make the argument that a system of markets maximizes society's welfare, economics necessarily adopts a particularly extreme form of individualism, abstracts knowledge from context, limits the community to the nation, and posits boundless consumption as the goal of life. With these assumptions at its core, economics offers us no way of thinking about sustainability, equity, and the human relationships that are the heart and soul of community other than as instrumental to the individual pursuit of happiness. Economics takes very much to heart the famous dictum of the nineteenthcentury physicist Lord Kelvin that we know only what we can measure. Indeed, economics takes the dictum a step further, from epistemology to ontology: what we can't measure-entities like community-doesn't exist. We shall need a new economics to prepare the way for a social order that takes community seriously. 